three editions, and contains information on 35 new universities in addition to its standard features. The contents of the two volumes are changed slightly; the chapter previously headed Great Britain in volume one has been moved to volume two as the United Kingdom. For the first time, chapters on the Bahamas, Bahrain, Botswana, Brunei, Oman, and the United Arab Emirates are included. Volume two ends with a 140-page index on institutions. The World of Learning 1974-75, 25th edn. Europa Publications Ltd., London. $£ 18.50$ two-volume set.

\section{Medical Photography}

The annual exhibition of the Medical Group of the Royal Photographic Society is now on show in the Claire Wand Gallery, B.M.A House. The exhibition was opened on 6 March by Sir Ronald Tunbridge, president of the B.M.A., and will oontinue until 25 April. The British Medical fournal award was won by Mr. R. Williams for his demonstration of Lichtschnitteverfahren and the Lancet trophy by Miss J. Fendick for the illustrations she prepared for $A$ Colour Atlas of Forensic Pathology.

\section{Resignations from G.P.s}

Well over 10000 undated resignations from the N.H.S. signed by general practitioners had been received by the B.M.A. at the end of last week. As we went to press the resignations were arriving at B.M.A. House at the rate of 1000 a day.

\section{COMING EVENTS}

Biological Engineering Society (Ultrasound and Blood Flow Groups). - Open day discussion meeting, "Haemodynamic Assessment by Ultra-
sonic Techniques in Clinical Practice," 27 March, Harrow. Fee $£ 1.75$ (including lunch). Applications Harrow. Fee $f 1 \cdot 75$ (including lunch). Applications
to L. H. Light, Bioengineering Division, Clinical to L. H. Light, Bioengineering Division, Clinical ford Road, Harrow, Middlesex HA1 3UJ. (Tel. 01-864 5311.)

British Small Animal Veterinary Association.-Annual congress, 4-6 April, Kensington, London. Details from Mr. T. M. Eaton, $5 \mathrm{St}$. George's Terrace, Cheltenham, Glos.

Society for Drug, Research.-(1) Day symposium, "Prolactin," 8 April, Chelsea College, Manresa Road, London S.W.3; (2) symposium, sity. Details from the secretary, Dr. Alma B. Simmonds, at Chelsea College.

International Symposium on Pyrogens.8-9 April, University College, London, organized by the Pharmaceutical Society of Great Britain. Fee $£ 15$ (including refreshments). Details and application forms from Mr. R. E. Marshall, at the society, 17 Bloomsbury Square, London WC1A

Institute of Practitioners in Work Study Organization and Methods (Health Services Specialist Group).- Spring conference, 9 April, Walsgrave Hospital, Coventry. Details and application forms from Mr. M. W. Goad, Regional Management Services Officer, North-west Thames Regional Health Authority, 40 Eastbourne
Terrace, London W.2. (Tel. 01-262 8011.)

"Communication and the X-ray Department."-Symposium, 9-11 April, Keele University. Fee $€ 18 \cdot 50$. Details from Dr. A. W. O'Malley, X-ray Department, North Staffs Royal Infirmary, 7 LN, Staffs.

Association of Anaesthetists of Great Britain and Ireland.-Annual scientific meeting for junior anaesthetists, 9-12 April, Birmingham University. Details from the secretary, Association of Anaesthetists, Room 475/478, Tavistock House South, Tavistock
(Tel. 01-387 4782.)
Welsh National School of Medicine.-Day, symposium, "Hypertension in the Older Patient,", 11 April, University Hospital of Wales, Heath Pathy, at the hospital. (Tel. 0222 755944.)

Royal College of General Practitioners.Annual spring general meeting, 11-13 April, Dundee. Details and application forms from the honorary secretary, East Scotland Faculty, Andrews, KY16 9DJ.

"Diffusion in Pharmaceutical Formulation and Packaging."-Postgraduate school, 14-18 April, London, organized by the School of Pharmacy, London University, and Pharmaceutical Pharmacy, London University, and Pharmaceutical application forms from the school secretary, Mr. R. E. Marshall, Department of Pharmaceutical Sciences, Pharmaceutical Society of Great Britain, 17 Bloomsbury Square, London WC1A 2NN.

Biochemical Society.-Meeting, 15-16 April, Aberystwyth, programme includes colloquium on "Biochemistry of Blue-green Bacteria." Details from the society, 7 Warwick Court, Hond
London WC1R 5DP. (Tel. 01-242 1076.)

U.K. Liaison Committee for Sciences Allied to Medicine and Biology.-Congress on April, Oxford. Details from Mr. R. E. George, S.A.M.B. Publicity Officer, Department of Clinical Physics and Bioengineering, Guy's Hospital, London SE1 9RT. (Tel. 01-407 7600, extn. 326.)

"Forensic Psychiatry."-Intensive residential course, 21-24 April, Birmingham University. Fee $f_{2} 2(£ 16.50$ non-residents). Details from the director, Board of Graduate Clinical Studies, 021-472 1301.)

\section{SOCIETIES AND LECTURES} For attending lectures marked a fee is charged
or a ticket is required. Applications should be
made first

Tuesday, 18 March

LONDON SOCIETY OF FAMILY PLANNING Doctors.At Royal Society of Medicine, 1 Wimpole Street, W.1, 8.15 p.m., meeting: Current Approaches to Treatment of Sexual Inadequacy.

OYAL ARMY MEDICAL College.-5 p.m., Dr.

C. A. H. Watts: Depression, a Protean Syndrome.

Wednesday, 19 March

Institute OF Dermatology.-4.30 p.m., Dr. M. Feivel: Xanthomatosis.

PARMACEUTICAL SocietY OF GREat BRtTain.-7 p.m., Dr. J. Taylor: Role of Forensic Laboratory
in Cases of Poisoning.

Fred COLLEGE OF SURGEONS OF ENGLAND. 4 p.m. Frederic Hewitt lecture by Professor

ROYAL POSTGRADUATE MEDICAL SCHOOL. -2 p.m., Professor I. Phillips: Antimicrobial Susceptibility of Anaerobe

Royal Society of Medicine: Section of ComparaTIVE MEDICINE.-2.30 p.m. joint meeting with
Royal Society of Tropical Medicine and Hygiene: Royal Society of Tropical Medicine and Hygiene: Prevention and Control of Parasitic Diseases.

WILIESDEN GENERAL HOSPITAL.- 8.30 p.m., Dr. M

\section{Thursday, 20 March}

Faculty OF HoMolopathy - 5 p.m., Richard Hughes memorial lecture by Dr. Kathleen G.
Priestman: Comments on Some Homoeopathic Remedies.

\section{Friday, 21 March}

INSTITUTE OP LARYNGOLOGY AND OTOLOGY.-5.30 p.m., Mr. E. J. Radley Smith: Fractures at Research in progress: Endocrinology.

\section{Saturday, 22 March}

ROYAL COLLEGE OF SURGEONS OF ENGLAND.-12 Woon, Webb-Johnson lecture basing the Gate to Pain.

\section{UNIVERSITIES AND COLLEGES}

CAMBRIDGE

M.D. -K. R. Hunter, I. C. Gregory. M.D. - K. R. Hunter, I. C. Gregory. E. Edwards,
M. G. W. Kettlewell, R. W. Marcuson.
ABERDEEN

Appointments.-Mr. J. R. C. Logie, Mr. J.

ROYAL COLLEGE OF SURGEONS IN

F.R.C.S.I.-A. El T. El Tahir. J. Harty, Rosaleen
E. Healy, F. Mosawi, M. J. Murphy, K. N. Rao, S. H. Surasi, A. U. I. Yakubu.

ROYAL COLLEGE OF SURGEQNS OF At a meeting of the council of the college held on
7 March the following were admitted to the fellowC. K. Aravindakshan, M. Chellappa, W. R. Chen, G. On Tong, D. Hung-Fai Cheng, Hing-Ping Chow, Hoi-Chu Fung, Hon-Lau Ho, Kam-Hing Lam, Abdel-Rahman, N. K. Agarwala, W. O. Aina, N. A.
Akingbehin, M. Akram, M. A. J. Al-Ani, S. S. AlAkingbehin, M. Akram, M. A. J. Al-Ani, S. S. AlN. A. Attar, S. S. Aujla, J. S. O. Aunallah, S Bagchi, F. S. Bassili, M. H. A. Beg, S. BhattacherChakraborty, R. E. Cheeks, P. B. Brew, A. K. M. A. Coe, G. F. Crisp, J. L. Croser, G. Dattani, E. F. D'Costa, S. N. Deliyannis, B. A. Deshmukh, J. P. Dhasmana, R. A. Dimitri, P. C. Dobson, Elliot, M. M. H. El Maaita, J. V. Forrester, I. S. Fyfe, I. R. Gough, C. K. Goyal, A. M. Greenberg, N. Y. Hamadalla, A. I. Hashmat, R. Hettiarachi, Wilson, B. R. Jaidev, H. K. Jolding, A. D. HoltL. Jha, W. G. Jhagroo, J. John, D. T. Johnson, Lall, E. R. Levy, P. N. I. Mash, P. Kollintzas, S. N. R. Maximose, M. Mendhi, J. S. Morcous, A. A. Morgan, R. A. M. Myers, Evelyn P. Nackasha,
J. F. O'Brien, A. O. A. Olusanya, A. F. C. Pinto,
F. Portelli, K. A. Oidwai. S M O F. Portelli, K. A. Qidwai. S. M. Qureshi, V. K.
Raju, N. Ramanathan, V. P. V. Rao, K. K. Ray, S. M. Read, A. K. Rohatgi, H. T. Saad, S. K. A. V. Shah, S. Shanmugham, R. Shome, B. L. E. D. J. Stone. K. J. Sunderland, Myo Swe, A. R Taylor, $M$. T. Thoung, M. G. Thuse, P. N. Tiwari,
$B$. H. Valentine, $P$. Vijayan, $R$. B. Warne, $M$. R Weedon, D. L.' Williams, W. F. Wong, H. I. A

\section{Corrections}

General Medical Council: Tests for Overseas Doctors

In the General Medical Council's report on tests for overseas doctors ( 8 March, p. 588) it was incorrectly stated that the tests would be considered at centres situated in London, Edinburgh, and Glasgow. The sentence should have read "The London, Edinburgh, and Glasgow."

Central Committee for Hospital Medical Services

In the report of the meeting of the C.C.H.M.S. (1 March, p. 529) Mr. D. H. Teasdale reported the outcome of a meeting of consultants. This meeting was attended by 60 members of the North West Regional Committee for Hospital Medical Services and the Hospital Consultants and Specialists Association. The 60 represented over 800 consultants. We apologize for this omission.

\section{Notice to Authors}

When original articles and letters for publication are not submitted exclusively to the British Medical fournal this must be stated.

Correspondence on editorial business should be addressed to the Editor, British Medical fournal, B.M.A. House, Tavistock Square, London ACItiology, London, W.C.1

Authors wanting reprints of their articles should notify the Publishing Manager, B.M.A. House, Tavistock Square, WC1H 9JR, on receipt of proofs.

\section{C) British Medical Journal 1975}

All Rights Reserved. No part of this publication may be reproduced, stored in a retrieval system, or transmitted, in any form or by any means, electronic, mechanical, photocopying, recording or otherwise, without the prior permission of the British Medical fournal. 